\title{
The Effect of Lekhana Basti in the Management of Sthoulya
}

\author{
Research Article
}

\author{
Ramachandra Nisargi $^{{ }^{*}}$, Pankaj Pathak ${ }^{2}$, Mythrey R C ${ }^{3}$ \\ 1. Asst.Prof, Dept. of Kaya Chikitsa, 2. Lecturer, Dept. of Basic Principles \\ JSS Ayurvedic Medical College, Mysore \\ 3. Asst.Prof, Dept. of Kaya Chikitsa, Government Ayurvedic Medical College, Mysore
}

\begin{abstract}
The study was formulated to evaluate the effect of lekhana basti over Amrutadya guggulu as a shamanoushadhi. The controlled group received placebo for sixteen days and Amrutadya guggulu along with diet and exercise for thirty two days, whereas test group received a course of lekhana basti for sixteen days along Amrutadya guggulu with diet and exercise for thirty two days. The duration of the treatment for both groups was 48 days. The mean scores levels of BMI, SFT, weight, vaksha pramana, spik pramana, vama bahu pramana and lipid profiles before and after the treatment of both groups were subjected for student's ' $t$ ' test with paired and unpaired methods. A significant response was obtained in both groups higher response was seen in test group in the signs and symptoms and also response in lipid profile levels. The difference between reduction in BMI, SFT, weight vaksha pramana, udara pramana and lipid profile between the two groups were significant with $\mathrm{P}>0.05$. The high reduction, in levels of VLDL and triglyceride cholesterol SFT, udara and spik pramana shows that lekhana basti has significant role in the management of sthoulya.
\end{abstract}

Key words: Sthoulya, lekhana basti, Amrutadya guggulu,

\section{Introduction:}

Obesity is the most common nutritional disorder in the present situation. With the mechanization of industry, and improved lifestyles, the proportion of people who take adequate exercise has declined and the number of sedentary workers including office workers and business executives has increased. With the possible complications it is not surprising that overweight is associated with an increased rate of mortality at all

*Corresponding Author:

Ramachandra Nisargi

Assistant Professor

Department of Kaya Chikitsa

JSS Ayurvedic Medical College

Mysore

E-mail: drramji_nisargi@yahoo.co.in ages. Thus the diagnosis and effective treatment of obesity is literally of vital importance. In the contemporary medical science, there is a lack of effective treatment. The most realistic approach today is to reduce, the weight in a much easier way and then educate the patient to follow a diet programme designed to provide $1200 \mathrm{Kcal}$ per day, along with moderate exercise. A good number of drugs have been explained by our Acharyas in Ayurveda in treating the sthoulya. Acharya Charaka has dealt in detail about the sthoulya(1) under the context of "ashtou ninditeeya adhyaya". While explaining the disease sthoulya, under the context of "Dwividhopakramaneeya adhyaya" Acharya Vagbhata opines that the disease sthoulya develops due to brimhana(2) ie., 
over nourishment From this perspective the study is conducted to know the efficacy of the lekhana basti in the management of sthoulya along with Amrutadya Guggulu, followed by diet and exercise.

\section{Materials and Methods}

The materials taken for the study were,

a) Drugs
1. Kusumabhaya - cap
2. Murchita tila taila
3. Lekhana basti
4. Placebo cap
5. Amrutadya guggulu

\section{b) Instruments}

1. Screw guage

2. Weighing machine

3. Measuring tape

c) Investigations

1. Lipid Profile

1. Drugs : Cap.Kusumabhaya, Murchita tila taila, Lekhana basti, Placebo cap, Amrutadya guggulu

2. Lekhana Basti(3) Materials : Triphala kwatha - 300ml, Gomutra100ml, Madhu - $30 \mathrm{ml}$, Yavakshara 2gm, Ushakadi gana dravya kalka 5gm, Tila taila and - 50ml, Saindhava - $12 \mathrm{gm}$

3. Ingredients of Cap. Placebo : Corn powder

4. Amrutadya Guggulu(4) (Amruta, Ela, Vidanga, Indrayava, Kutaja, Hareetaki, Amalaki and Shuddha Guggulu)

\section{Methods}

Sampling - For clinical trials 22 patients were incidentally selected from the out patient department of Government Ayurvedic Medical College, Mysore.

\section{Criteria for the Selection of Patients}

The selection of the patients, for the study was done with the following criteria.
1) The patients for the primary diagnosis of obesity (BMI > 30, sthoulya), were selected for the study.

2) Patients of either sex, between the age group of 20-50 years, were selected.

3) The signs and symptoms of sthoulya as explained in our classics.

4) Obesity due to excessive calories. (calories intake is more, but life style is sedentary then it is the cause of obesity)

\section{Criteria for Exclusion}

1) Patients having the complications of obesity (sthoulya) such as diabetes mellitus, scitica, varicose veins, osteo arthritis, and cardio vascular disorders were excluded.

2) Patients having other systemic disorders were excluded.

3) Obesity (sthoulya) due to endocrine disturbance were excluded.

4) Patients who are not fit for basti karma were excluded.

\section{Research Design}

After the diagnosis, as on the above parameters, the selected patients were assigned into two identical groups of eleven patients in each group. It is single blind controlled study. All the patients were treated as out patient only Pre-test and post - test readings were taken to assess the measurement of chest, abdomen, hip and left arm and lipid profiles. Group A received cap - Kusumabhaya lekhana basti and cap -Amrutadya guggulu along with diet and exercise treated as test group. Group B received cap -Kusumabhaya followed by placebo capsules and Amrutadya guggulu with diet and excise serving as a control group.

Group A: The patients were administered cap. Kusumabhaya 2 capsules, at bed time with leuke warm water for the purpose of anulomana, for one day followed by lekhana basti for 16 days, during the period of parihara kala ie., 32 days, patients received cap - 
Amrutadya guggulu 2 tds with luke warm water as anupana, along with diet and exercise.

Group B: The patients were received cap - Kusumabhaya 2 at bed time for the purpose of anulomana for one day followed by placed capsules. 2 bd. with sukhoshna jala as anapana for 16 days during next 32 days, patients received Amrutadya guggulu 2 BD with sukhoshna jala as anupana along with diet and exercise similar to that of Group A.

\section{Methods of Lekhana Basti}

The duration of lekhana basti was 16 days. In this course 10 anuvasana basti with murchita tila taila $(80 \mathrm{ml}$ in single dose) and six nirooha bastis with lekhana basti were administered (5).

The anuvasana basti was administered, on that morning after evacuation of bowels and bladder, patient was advised to take light food at $9.30 \mathrm{am}$. then patient was subjected for abhyanga to nabhi, kati, prusta, and parshwa with tila taila and sweda with patra potali for about twenty minutes. Then the patient was asked to lie down on the table in the left lateral position, with the left knee extended, right limb flexed and resting on the left knee. The head was supported by the patients left hand. The plastic glycerine enema syringe, with a capacity of $100 \mathrm{ml}$ and plane rubber catheter of size no.12 were used for the purpose of anuvasana basti. The anal orifice and the inserting end of the syringe were smeared with oil for lubrication. The eaema syringe filled with Murchita tila taila was gently inserted to about 4 inches in to the rectum parallel to the spinal column.

Simultaneously the patient was asked to take deep breaths. The enema syringe was removed with some of the drug still remaining in the syringe to prevent the entry of air into the colon. Then the patient was asked to turn to the supine position, and his buttocks were gently patted and his palm and soles were rubbed. Patients were asked to remain in the same position for 10 minutes. The patient was watched for the evacuation of the drug. After evacuation they were allowed to take hot water bath and then light food.

The quantity of murchita tila taila taken was $80 \mathrm{ml}$. The course of lakshana basti was started with two anuvasana bastis of murchita tila taila and then it was given in alternate days.

The nirooha Basti was started on the third day of the course. The nirooha basti dravya was prepared at the time of administration. First $30 \mathrm{ml}$ of Madhu and 12 grams of finely powdered saindhava lavana was taken in the mortar and are mixed. Then $50 \mathrm{ml}$ of Murchita tila taila was added slowly till they get properly mixed. Then 5 gms of Ushakadi gana dravya kalka was added and are mixed. After that $300 \mathrm{ml}$ of Triphala kwatha mixed into the mortar. Finally $100 \mathrm{ml}$ of filtered Gomutra was added slowly and all were mixed well till it gets a uniform consistency. This was filtered and indirectly warmed in a boiling water vessel to make it lukewarm. The nirooha basti was given in the similar manner to that of anuvasana basti. Like all niroohas it was administered before taking food. The poorva karma, pradhana karma and paschat karma were similar to that of Anuvasana. Plastic enema can with the capacity of $1200 \mathrm{ml}$ was taken instead of enema syringe. The patient was advised to remain on the table till he feels the urge of defecation. After defecation they were allowed to take hot water bath and then light food. The quantity of lekhana Basti administered was $499 \mathrm{ml}$ a day. The patient was advised to take cap Amrutadya Guggulu along with diet and excised after the completion of Basti course, for 32 days, to complete the 48 days of the treatment program.

\section{Criteria for Assessment of Results}

In this clinical study to know the effect of lekhana basti on the BMI, 
circumferences of chest, abdomen,hip and left arm and lipid profiles, gradation was not given in this context.

Two assessments of the patients were made before and after the treatment. The most widely used formula for relating height and weight is the body mass index (BMI) which is a weight /(height in meter). The B.M.I, circumference of the chest, abdomen, hip and left arm and lipid profiles levels were subjected to statistical analysis by applying students paired ' $t$ ' test, when they were compared with baseline before and after the treatment in both the groups. For statistical analysis at the end of the treatment between groups, the students unpaired ' $\mathrm{t}$ ' test was applied. ' $\mathrm{P}$ ' value was calculated by referring to Fischer's table at the corresponding level of degree of freedom. In the present study, seventy two patients were registered out of which there were fifty dropouts during the various stages of the treatment. In twenty two patients the clinical study was completed among these patients, there were six males and sixteen female patients.

RESULTS

In the present study, seventy two patients were registered out of which there were fifty dropouts during the various stages of the treatment. In twenty two patients the clinical study was completed.

Table No. 1 Showing the Statistical Analysis of Mean Weight Loss before and after treatment in both Groups

\begin{tabular}{|c|c|c|c|c|c|c|c|}
\hline Group & Mean & SD & $\mathrm{SE}$ & PSE & $\mathrm{T}$ & $\mathrm{P}$ & Remark \\
\hline \multicolumn{8}{|c|}{ Group A } \\
\hline B.T. & 80.54 & 16.31 & 4.91 & & & & \\
\hline A.T. & 77.95 & 16.07 & 4.84 & 6.89 & 0.37 & $>0.05$ & NS \\
\hline $\mathrm{D}$ & 2.68 & 1.10 & 0.33 & -- & 8.07 & $<0.05$ & $\mathrm{HS}$ \\
\hline \multicolumn{8}{|c|}{ Group B } \\
\hline B.T. & 77 & 8.25 & 2.48 & & & & \\
\hline A.T & 72.77 & 8.25 & 2.48 & 3.52 & 1.2 & $>0.05$ & N.S \\
\hline $\mathrm{D}$ & 4.22 & 1.80 & 0.54 & -- & 7.75 & $<0.05$ & H.S \\
\hline
\end{tabular}

Table No. 2 Showing the Statistical Analysis of Mean BMI, before and after the treatment in both Groups

\begin{tabular}{|c|c|c|c|c|c|c|c|}
\hline Group & Mean & SD & $\mathrm{SE}$ & PSE & $\mathrm{T}$ & $\mathrm{P}$ & Remark \\
\hline \multicolumn{8}{|c|}{ Group A } \\
\hline B.T. & 34.01 & 4.38 & 1.32 & & & & \\
\hline A.T. & 31.99 & 3.51 & 1.06 & 1.69 & 1.19 & $>0.05$ & NS \\
\hline D & 2.02 & 2.16 & 0.65 & -- & 3.1 & $<0.05$ & H.S \\
\hline \multicolumn{8}{|c|}{ Group B } \\
\hline B.T. & 32.03 & 1.96 & 0.59 & & & & \\
\hline A.T & 29.12 & 1.33 & 0.40 & 0.71 & 0.04 & $<0.05$ & H.S \\
\hline $\mathrm{D}$ & 2.78 & 3.65 & 1.10 & -- & 2.52 & $<0.05$ & H.S \\
\hline
\end{tabular}

Table No. 3 Showing Statistical Analysis of mean S.F.T. before and after the treatment in both Groups

\begin{tabular}{|c|c|c|c|c|c|c|c|}
\hline Group & Mean & SD & $\mathrm{SE}$ & PSE & $\mathrm{T}$ & $\mathrm{P}$ & Remark \\
\hline \multicolumn{8}{|c|}{ Group A } \\
\hline B.T. & 11.04 & 1.81 & 0.54 & & & & \\
\hline A.T. & 8.53 & 2.08 & 0.60 & 0.81 & 3.07 & $>0.05$ & NS \\
\hline $\mathrm{D}$ & 2.53 & 2.41 & 0.72 & --- & 3.48 & $<0.05$ & HS \\
\hline
\end{tabular}




\begin{tabular}{|l|l|l|l|l|l|l|l|}
\hline Group B \\
\hline B.T. & 11.43 & 2.62 & 0.79 & & & & \\
\hline A.T & 9.8 & 1.71 & 0.51 & 0.94 & 1.67 & $>0.05$ & NS \\
\hline D & 1.55 & 0.59 & 0.3 & -- & 5.16 & $<0.05$ & HS \\
\hline
\end{tabular}

Table No. 4 Showing Statistical Analysis of mean Vaksha Pramana before and after treatment in the both Groups

\begin{tabular}{|c|c|c|c|c|c|c|c|}
\hline Group & Mean & SD & $\mathrm{SE}$ & PSE & $\mathrm{T}$ & $\mathrm{P}$ & Remark \\
\hline \multicolumn{8}{|c|}{ Group A } \\
\hline B.T. & 101.76 & 11.36 & 3.42 & & & & \\
\hline A.T. & 97.18 & 10.88 & 3.2 & 4.74 & 0.95 & $>0.05$ & NS \\
\hline $\mathrm{D}$ & 9.63 & 0.92 & 0.27 & --- & 13.03 & $<0.05$ & H.S \\
\hline \multicolumn{8}{|c|}{ Group B } \\
\hline B.T. & 99.45 & 4.13 & 1.24 & & & & \\
\hline A.T & 97.27 & 4.22 & 1.27 & 1.78 & 1.22 & $>0.05$ & NS \\
\hline $\mathrm{D}$ & 2.18 & 1.94 & 0.58 & --- & 3.73 & $<0.05$ & HS \\
\hline
\end{tabular}

Table No. 5 Showing Statistical Analysis of Mean Udara Pramana before and after treatment in the both Groups

\begin{tabular}{|c|c|c|c|c|c|c|c|}
\hline Group & Mean & SD & $\mathrm{SE}$ & PSE & $\mathrm{T}$ & $\mathrm{P}$ & Remark \\
\hline \multicolumn{8}{|c|}{ Group A } \\
\hline B.T. & 102.86 & 12.42 & 3.81 & & & & \\
\hline A.T. & 97.18 & 12.51 & 3.77 & 5.36 & 1.05 & $>0.05$ & NS \\
\hline $\mathrm{D}$ & 4.77 & 3.25 & 0.98 & --- & 4.86 & $<0.05$ & HS \\
\hline \multicolumn{8}{|c|}{ Group B } \\
\hline B.T. & 99.63 & 8.11 & 2.44 & & & & \\
\hline A.T & 94.0 & 6.34 & 1.91 & 3.10 & 1.81 & $>0.05$ & N.S \\
\hline $\mathrm{D}$ & 5.09 & 4.67 & 1.41 & --- & 3.60 & $<0.05$ & H.S \\
\hline
\end{tabular}

Table No. 6 Showing Statistical Analysis of Mean Spik Pramana before and after treatment in the both Groups

\begin{tabular}{|c|c|c|c|c|c|c|c|}
\hline Group & Mean & SD & $\mathrm{SE}$ & PSE & $\mathrm{T}$ & $\mathrm{P}$ & Remark \\
\hline \multicolumn{8}{|c|}{ Group A } \\
\hline B.T. & 115 & 9.7 & 2.95 & & & & \\
\hline A.T. & 108.81 & 9.4 & 2.83 & 4.09 & 1.51 & $>0.05$ & N.S \\
\hline $\mathrm{D}$ & 5.7 & 3.03 & 0.91 & --- & 5.75 & $<0.05$ & H.S. \\
\hline \multicolumn{8}{|c|}{ Group B } \\
\hline B.T. & 105.36 & 4.71 & 1.42 & & & & \\
\hline A.T & 101.90 & 5.31 & 1.60 & 1.77 & 1.94 & $>0.05$ & N.S. \\
\hline $\mathrm{D}$ & 3.63 & 2.87 & 0.6 & --- & 4.19 & $<0.05$ & H.S \\
\hline
\end{tabular}

Table No. 7 Showing Statistical Analysis of Mean Vama Bahu Pramana before and after treatment in the both Groups.

\begin{tabular}{|l|l|l|l|l|l|l|l|}
\hline Group & Mean & SD & SE & PSE & T & P & Remark \\
\hline Group A \\
\hline B.T. & 30.22 & 2.99 & 0.90 & & & & \\
\hline
\end{tabular}




\begin{tabular}{|l|l|l|l|l|l|l|l|}
\hline A.T. & 28.45 & 2.50 & 0.75 & 1.17 & 1.50 & $>0.05$ & NS \\
\hline D & 1.68 & 1.14 & 0.34 & --- & 4.86 & $<0.05$ & HS \\
\hline Group B \\
\hline B.T. & 28.13 & 1.48 & 0.44 & & & & \\
\hline A.T & 27.36 & 1.74 & 0.52 & 0.69 & 1.17 & $>0.05$ & NS \\
\hline D & 0.77 & 1.29 & 0.38 & --- & 1.9 & $<0.05$ & NS \\
\hline
\end{tabular}

Table No. 8 Showing Statistical analysis of Means Lipid Profiles before and after treatment in Group A

\begin{tabular}{|c|c|c|c|c|c|c|c|}
\hline Group & Mean & SD & SE & PSE & $\mathrm{T}$ & $\mathrm{P}$ & Remark \\
\hline \multicolumn{8}{|c|}{ Total Cholesterol } \\
\hline B.T. & 202.81 & 43.38 & 13.08 & & & & \\
\hline A.T. & 207.18 & 61.72 & 18.61 & 22.74 & 0.19 & $>0.05$ & NS \\
\hline $\mathrm{D}$ & 39.81 & 36.97 & 11.14 & --- & 3.57 & $<0.05$ & $\mathrm{HS}$ \\
\hline \multicolumn{8}{|l|}{ HDL } \\
\hline B.T. & 47.10 & 6.69 & 2.01 & & & & \\
\hline A.T & 47.77 & 7.49 & 2.25 & 3.03 & 0.21 & $>0.05$ & NS \\
\hline $\mathrm{D}$ & 3.93 & 2.28 & 0.68 & --- & 5.71 & $<0.05$ & $\mathrm{HS}$ \\
\hline \multicolumn{8}{|l|}{ LDL } \\
\hline B.T. & 121.85 & 41.29 & 12.45 & & & & \\
\hline A.T & 125.73 & 51.76 & 15.60 & 19.96 & 0.19 & $>0.05$ & $\mathrm{NS}$ \\
\hline D & 31.62 & 30.05 & 9.06 & --- & 3.49 & $<0.05$ & $\mathrm{HS}$ \\
\hline \multicolumn{8}{|l|}{ VLDL } \\
\hline B.T. & 33.89 & 10.95 & 3.30 & & & & \\
\hline A.T & 33.12 & 11.33 & 3.41 & 4.75 & 0.16 & $>0.05$ & $\mathrm{NS}$ \\
\hline $\mathrm{D}$ & 6.90 & 4.51 & 1.36 & -- & 5.07 & $<0.05$ & $\mathrm{HS}$ \\
\hline \multicolumn{8}{|c|}{ Triglycerides } \\
\hline B.T. & 169.63 & 54.83 & 16.53 & & & & \\
\hline A.T & 164.18 & 55.98 & 16.88 & 23.62 & 0.23 & $>0.05$ & $\mathrm{NS}$ \\
\hline D & 36.72 & 27.90 & 8.41 & --- & 4.36 & $<0.05$ & $\mathrm{HS}$ \\
\hline
\end{tabular}

Table No. 9 Showing Statistical analysis of Means Lipid Profiles before and after treatment in Group B

\begin{tabular}{|l|l|l|l|l|l|l|l|}
\hline Group & Mean & SD & SE & PSE & T & P & Remark \\
\hline Total Cholesterol \\
\hline B.T. & 225.63 & 52.61 & 15.86 & & & & \\
\hline A.T. & 202.81 & 22.55 & 6.8 & 17.26 & 1.32 & $>0.05$ & NS \\
\hline D & 37.27 & 59.41 & 17.91 & --- & 2.08 & $<0.05$ & HS \\
\hline HDL & 49.81 & 4.97 & 1.50 & & & & \\
\hline B.T. & 47.54 & 6.23 & 1.87 & 2.40 & 0.94 & $>0.05$ & NS \\
\hline A.T & 5 & 6.46 & 1.94 & --- & 2.56 & $<0.05$ & HS \\
\hline D & LDL & \multicolumn{7}{|l|}{} & & \\
\hline B.T. & 136.41 & 50.0 & 15.07 & & & & NS \\
\hline A.T & 119.96 & 18.78 & 5.56 & 16.10 & 1.02 & $>0.05$ & HS \\
\hline D & 35.38 & 50.27 & 15.15 & --- & 2.33 & $<0.05$ & \\
\hline VLDL
\end{tabular}




\begin{tabular}{|l|l|l|l|l|l|l|l|}
\hline A.T & 29.76 & 3.60 & 1.08 & 3.67 & 2.27 & $>0.05$ & NS \\
\hline D & 10.63 & 11.50 & 3.46 & --- & 3.0 & $<0.05$ & H.S \\
\hline Triglycerides \\
\hline B.T. & 191.54 & 58.19 & 17.54 & & & & \\
\hline A.T & 143.81 & 22.49 & 6.78 & 18.81 & 2.53 & $>0.05$ & NS \\
\hline D & 53.45 & 51.92 & 15.65 & --- & 3.41 & $<0.05$ & HS \\
\hline
\end{tabular}

\section{Discussion}

After the study, confirmed that both lekhana basti and Amrutadya Guggulu have their own role in the management of sthoulya, as the patients belonging to the both groups shown marked reduction in weight, S.F.T, H.D.L, V.L.D.L and Triglyceride cholesterol levels and measurements like udara and spik pramanas.

After the treatment, when overall assessment was done to assess the improvement between the groups, the lekhana basti group shown highly significant in weight, V.L.D.L and Triglycerides cholesterol levels and measurements like udara and spik pramanas. But controlled group also shown marked deviation in the mean levels of VLDL and Triglycerides. And this group also shown marked reduction in the udara and spik measurements. Controlled group shown no (improvement) increase in HDL levels in 3 patients (27.27\%), LDL levels in 3 patients $(27.27 \%)$ and also increase in triglyceride levels in one patient $(9.09 \%)$.

At the end of 32 days, when the marked reduction in the measurements (udara and spik), weight, VLDL, triglyceride levels were compared between groups, the lekhana basti group shown higher level of reduction in the measurements, weight and VLDL and triglyceride levels.

Lekhana basti group shown that high level reduction in all "deviated" cholesterol levels. i.e., Total cholesterol HDL, LDL, VLDL and Triglycerides are highly significant. Where as total cholesterol and HDL cholesterol levels is statistically significant in controlled group. The variations of controlled group (square of S.D) is more than the test group.

If we compare, within the group depending upon the ' $\mathrm{P}$ ' values of the test group are not significant, whereas it is highly significant in deviation. This is may be due to reasons like improper intake medicine, food etc.

The SFT measurements of the test group were shown high reduction. Where it is reversed in BMI. In both groups, the variation of weight is almost same. The variance of spik, udara pramanas of the test group was highly significant then the controlled group. Though our Acharyas clearly mention that, style is kashta sadhya or Asadhya. This particular study was selected to make an attempt to reduce the risks of morbid condition and appreciate the guidelines issued in this study by Roland Jung that, when $10 \mathrm{~kg}$ weight loss is achieved the following are the benefits. So, based on above said statement the assurance was given to patients.

The results of the study confirmed that the incidence of sthoulya in female is more, compared to that of males. Twenty two cases of the present clinical study, the ratio also closely satisfies the established ratio.

In contemporary medical science, mentioned that, the incidence of obesity is higher in affluent society. This information holds good as far as this clinical study is considered with 9 of the 22 cases representing affluent society $(40.90 \%), 8$ representing upper middle $(36.36 \%)$ and 5 representing middle class $(22.72 \%)$. 
The allied science also states that obese patients with positive family history are comparatively higher. Here in this study the same holds good as the 15 patients were having a positive family history.

In Ayurveda it is mentioned that kapha doshaja prakruti persons are more prone to have kaphaja nanatmaja vikaras. Sthoulya one among the kaphaja nanatmaja vikaras, like wise the present clinical study conducted had 14 (63.63\%) of the 22 patients representing kaphaja prakruti.

After the study, confirmed that both lekhana basti and Amrutadya Guggulu have their own role in the management of sthoulya, as the patients belonging to the both groups shown marked reduction in weight, S.F.T, H.D.L, V.L.D.L and Triglyceride cholesterol levels and measurements like udara and spik pramanas.

After the treatment, when overall assessment was done to assess the improvement between the groups, the lekhana basti group shown highly significant in weight, V.L.D.L and triglycerides cholesterol levels and measurements like udara and spik pramanas. But controlled group also shown marked deviation in the mean levels of VLDL and Triglycerides. And this group also shown marked reduction in the udara and spik measurements. Controlled group shown no (improvement) increase in HDL levels in 3 patients $(27.27 \%)$, LDL levels in 3 patients $(27.27 \%)$ and also increase in triglyceride levels in one patient $(9.09 \%)$.

This signifies that lekhana basti possibly had a greater role in samprapti vighatana(Breaking of pathogensis).

At the end of 32 days, when the marked reduction in the measurements of udara and spik(Abdomen and waist), weight, VLDL, triglyceride levels was compared between groups, the lekhana basti group shown higher level of reduction in the measurements, weight and VLDL and triglyceride levels.

Lekhana basti group shown that high level reduction in all "deviated" cholesterol levels. i.e., Total cholesterol HDL, LDL, VLDL and Triglycerides are highly significant. Whereas total cholesterol and HDL cholesterol levels is statistically significant in the controlled group. The variations of a controlled group (square of S.D) are more than the test group.

\section{Conclusion}

Sthoulya is a disease which effectively represents obesity. Through both lekhana basti and Amrutadya guggulu have their own role in the management of sthoulya, the discussion about the clinical study revealed that lekhana basti has a significant role as higher percentage of reduction in BMI, SFT and VLDL cholesterol and triglyceride level was observed in the test group. Lekhana basti chikitsa found to be costly, easily available and very much effective, reducing in the levels of VLDL and triglyceride.

\section{References:}

1. Chakrapani (1991), Charaka Samhita, with Ayurveda Dipika Sanskrit Comm. Edr, Kaviraja Narendranath Sengupta and Balaichandra Sengupta Chaukhamba Orientalia, Varanasi, p. 786.

2. Arunadatta (1939), Astanga Hrudaya, 8th Edn, with Sarvanga Sundara, Sanskrit comm. Edr, Bhishagacharya Harisastri Paradakara vaidya, Chaukhamba Orientalia, Varanasi, pp. 225-228.

3. Sushruta (1987), Sushruta Samhita, 6th Edn, Hindi Comm, Edr, Kaviraja Ambikadatta Shastri, Chaukhamba Sanskrit Samsthana, Varanasi, pp. 6263.

4. Bhavamishra (1969), Bhavaprakash with Vidyotini Hindi comm. Vol.I, 5th Edn. Brahma Shankar Mishra and 
Rupalalji Vaisya Chaukhamba Sanakrit series Varanasi, p. 878.

5. Chakrapani (1991), Charaka Samhita, with Ayurveda Dipika Sanskrit Comm.
Edr, Kaviraja Narendranath Sengupta and Balaichandra Sengupta Chaukhamba Orientalia, Varanasi, p. 786. 